\title{
The Ignatian Suscipe Prayer: Its Text and Meaning
}

\author{
David Coffey ${ }^{1}$ \\ Marquette University, emeritus \\ david.coffey@sydneycatholic.org
}

\begin{abstract}
The article argues that the concluding sentence of the popular prayer of St. Ignatius Loyola (d.1556), "Take, Lord, Receive," was interpreted by the Saint himself and his translator and contemporary, André des Freux, as a petition for the gift of the love of God in the sense of our love for God rather than God's love for us. It argues further that this sense was rendered fully explicit by the twentieth-century commentator Édouard Gueydan. Finally, recognizing the achievement of these two theologians, it recommends the general adoption of their version of the prayer.
\end{abstract}

\section{Keywords}

André des Freux - Contemplation to Attain Love - Édouard Gueydan - fundamental theology - Ignatius of Loyola - Spiritual Exercises - Suscipe

\section{In Memory of Rev. F. Paul Prucha, S.J.}

In this article, my concern is to determine as accurately as possible the "best text" of the "Suscipe" prayer of St. Ignatius of Loyola ("Take, Lord, Receive") found in his well-known work, the Spiritual Exercises. By "best text" I mean that one of the four on "offer" - I will explain this later - that most truly represents the mind of St. Ignatius. In pursuit of this aim the article engages in a preparatory study in the field of fundamental theology. Every theological question has

1 David Coffey received his STD from the Catholic Institute of Sydney, of which he eventually became president. From 1998 to 2006 he held the William J. Kelly, S.J. Chair in Catholic Theology at Marquette University, where he is now professor emeritus. He specializes in the theologies of the Trinity, Christ, and grace. He retired in 2006.

(C) DAVID COFFEY, 2018 | DOI:10.1163/22141332-00504002

This is an open access article distributed under the terms of the prevailing CC-BY-NC license at the time of publication. 
behind it a fundamental theology, that is, a soundly based body of "natural" knowledge that provides the necessary foundation for a strictly theological treatment. It is called "fundamental" because it deals in fundamentals, foundations; it is called "theology" not by reason of its actual subject matter, but by reason of the purpose this subject matter is intended to serve.

At the heart of my article stands an argument, a combined linguistic and practical argument, which comes to certain (quaedam) conclusions about the way St. Ignatius himself saw his prayer. It follows from this that subsequent speculation on the meaning of the prayer will be governed by the intentions of St. Ignatius thus discovered, that is, from what he said (or wrote) and what he did, his words and deeds. After all, there is no other way in which the mind of a historical personage can be accessed. Knowledge thus gained is the yield of fundamental theology, and its outcome can be surprising, as in the present case, since a role for fundamental theology in a question of the present kind is seldom recognized, let alone allowed practical effect.

By "fundamental theology" I do not mean a presuppositionless theology, for there is no such thing. I simply mean a preparatory study that provides directions, both permissive and prohibitive, for the conduct of theology properly so called. Nor is it incumbent on fundamental theologians to say what use or uses can or should be made of their findings. There is really only one question they must concern themselves with: have I shown by my research that I have uncovered the true mind of St. Ignatius in regard to his prayer as found in the Exercises? If they have so shown, they can rest content. If the intention is other, for example, that people should be "consoled" or "helped" by the prayer, different criteria, which do not concern us here, must be invoked. (I am thinking of Louis Puhl's formulation from 1951, "Give me Thy love and Thy grace, for this is sufficient for me," and Elder Mullan's from 1909, "Give me Thy love and grace, for this is enough for me," for which this justification is sometimes claimed.) To my mind it is self-evident that in the present instance the only possible starting point is the truth insofar as it is available to us. Then let practitioners and others, acting on this basis, discover further uses according as they can. When scientists found that they could split the atom, it was essentially for others to determine how the newly discovered force was best to be harnessed in the service of humankind.

Allow me, at the outset, to reproduce the "Vulgate" or "common" text ("V"), the first of the three Latin versions of the prayer provided in the Monumenta Ignatiana. ${ }^{2}$ These three, plus the so-called Spanish autograph, comprise the

2 See Monumenta Ignatiana. Sancti Ignatii de Loyola, Exercitia Spiritualia: Textuum Antiquissimorum Nova Editio; Lexicon Textus Hispani. Monumenta Historica Societatis Iesu, vol. 100 (Rome: Institutum Historicum Societatis Iesu, 1969), 308 b. 
four texts referred to earlier that the Monumenta "offer" (hence my use of this precise word) as the principal texts of the Exercises. Further explanations will follow; for the moment, though, I merely want to place the text before the reader for the purpose of ready reference. Here, then, it is:

Suscipe, Domine, omnem meam libertatem. Accipe memoriam, intellectum atque voluntatem omnem. Quicquid habeo vel possideo, mihi largitus es: id totum restituo, ac tuae prorsus voluntati trado gubernandum. Amorem tui solum cum gratia tua mihi dones, et dives sum satis, nec aliud quicquam ultra posco.

Also for reference, I reproduce the widely used English translation of the prayer chosen for the reverse side of Father Prucha's memorial card:

Take, O Lord, and receive all my liberty, my memory, my understanding, and my entire will. Whatever I have or hold, You have given me; I restore it all to You and surrender it wholly to be governed by Your will. Give me only Your love and Your grace, and I am rich enough and ask for nothing more. ${ }^{3}$

Here as well as in V it is the concluding sentence that will constitute the object of our study. As stated earlier, by "best text" I mean the one that most truly represents the mind of St. Ignatius. It will not necessarily be the Spanish autograph, since it will contain positions that must be recognized as developments of positions taken in the autograph, developments that occurred in the creative interaction between André des Freux $\left(1515^{-56}\right)$ and Ignatius productive of $\mathrm{V}$. As a translation, the actual text, as I have already mentioned, was the work of des Freux, Frusius, as he was called in Latin (and hence the adjective "Frusian"). He was a French polymath and member of the small circle of early Jesuits. He was commissioned by St. Ignatius to undertake this work of translation. Latin translations appeared early in the history of the Exercises, because Latin was the language of the church and the lingua franca of the educated class. Ignatius wanted a new Latin translation to submit to the reigning pontiff for approval, for though he knew both Spanish and Latin, as a Basque, and as a nobleman rather than a scholar, he was expert in neither language. Hence the demand for, and production of $\mathrm{V}$, which remained the Saint's favored translation for the rest of his life. The mind of Ignatius is revealed not only in the text, that is, the "linguistic" component of the prayer in its historical setting, but in

3 The only acknowledgement supplied on the card is "Prayer of St. Ignatius." 
his relevant actions or practice subsequent to V. For want of a better term I call the latter the "practical" component. The combination of these can present, and has presented, problems of understanding that I address in the course of my article.

The order of presentation will be: first, to deal with the location of the prayer; then, to follow with the question of the different versions, not just of the prayer but of the Exercises as a whole. Finally, I will invite the reader to accompany me on the journey leading to my own conclusion as to the best text of the prayer.

The prayer has two early locations, the Spiritual Exercises and the Missale Romanum (hereafter MR). The "Fourth Week" of the Spiritual Exercises provides the first and primary location, in "The Contemplation to Attain Love," but where this contemplation itself (or simply the Contemplatio as it is called) best belongs within the Exercises - its present location is directly after the First Contemplation-is another matter, and not one that need occupy us here. ${ }^{4}$ What is important for us is the function of the prayer within the Contemplatio. It (the prayer) is found as the conclusion of the first of four "Points" comprising the Contemplatio.

When des Freux came to the translation of the prayer, he went beyond the earlier Spanish text and its other Latin translations. We will see that he had good reason for this. His action, however, focused attention on his translation of the prayer, particularly as it was this that $\mathrm{MR}$, the second (and secondary) location, adopted for its own purposes. In MR, the prayer is found, under the title "Oblatio sui" ("Offering of Oneself"), ${ }^{5}$ in the section Gratiarum actio post Missam ("Thanksgiving after Mass"). This indicates that MR chose it, in its Frusian formulation, as a prayer to be commended to the faithful for thanksgiving after Holy Communion, a purpose both actually and potentially wider in outreach than that of the Exercises.

We move on now to the second issue, namely, authoritative texts. A recent article by Eric Jensen provides up-to-date information on this matter. ${ }^{6}$ There are essentially three main contenders for the honor of most authoritative text.

4 Given that the Contemplatio could be presented as a statement of the main objective of the Exercises as a whole, the choice as to when best to introduce it appears to be left, within limits, to the discretion of the retreat-director.

5 Be it noted that the word "sui" here has the same function as "tui" in des Freux's phrase "amor tui," with which we will soon be engaged.

6 See Eric Jensen, "The Spanish Autograph or the Latin Vulgate?: A Return to the Sources of the Spiritual Exercises," The Way 53, no. 3 (July 2014): 79-86. 
The earliest of them is the Spanish autograph text of $1541 .^{7}$ The actual autograph text of St. Ignatius was lost, but a copy made by a secretary was retained, with hand-written corrections later supplied by the Saint. It can be accessed as the first of four basic texts provided in parallel columns in the Monumenta, in the Jesuit archive in Rome. ${ }^{8}$ The Spanish autograph text is known as " $\mathrm{A}$ " (for "autograph"), and for that reason is not considered a "version." The other three texts, the "versions," are V (1547) and two earlier Latin translations, P1 (1541) and $\mathrm{P}_{2}$ (an adaptation of $\mathrm{P}_{1}$ dated between 1541 and 1547 ), named "P" under the common title of Versio prima in distinction from $\mathrm{V}$. $\mathrm{V}$ and $\mathrm{P} 2$ deserve special attention because they were submitted together in 1547 to Pope Paul III and the Roman Curia for the approval granted in 1548. These two along with A are the three contenders to which I refer. $\mathrm{P}$, held to be the work of St. Ignatius himself, was never submitted to Rome; and the amendments which changed $\mathrm{P}_{1}$ into $\mathrm{P} 2$ were contributed by others, not by him. V alone among the versions was authored by a Latinist of distinction, namely, des Freux. Representing the best of scholarship, the four texts of the Monumenta are highly reliable and are much respected in the scholarly community. They constitute the principal authority to which I appeal in this article. As a secondary authority I acknowledge the unofficial and unpublished literal English translation (from A) of no. 234 made for me by Dr. Íñigo Martínez Echevarría, of Sydney, Australia. ${ }^{9}$

We are now in a better position to address the third issue, namely, to give an account of the process by which I reached my own conclusion as to the best text of the prayer. First, we must introduce a matter of terminology. Des Freux had designed his version as proof against misunderstanding. With regard to the prayer this meant that he was at pains to ensure by purely linguistic means that a particular, concrete instance of the genitive case in the text of the prayer could be recognized unmistakably as what is called today an "objective" genitive. Precisely what I mean by this will emerge as we proceed.

We embark, then, on the first part of the presentation of my case, namely, the linguistic argument. The key words on which it hangs are "amorem tui solum cum gratia tua mihi dones" in the last sentence of the prayer in $\mathrm{V}$, in which alone they occur. For the moment, I leave them untranslated. The specific question with which we begin is: Is "amor [amorem] tui" our love for God, or God's love for us? The traditional terminology in which the question of the love of God, "amor Dei," is discussed is that of "subject" and "object," "subjective genitive" and "objective genitive." Latinist B. L. Gildersleeve explains that when

\footnotetext{
7 See Jensen's article, p. 80 for this and the remaining references of the present paragraph.

8 See note 1 for the reference.

9 Dr. Martínez Echevarría's degree is in canon law from the University of Navarre.
} 
the substantive on which the genitive depends contains the idea of an action, the possession may be active or passive. ${ }^{10}$ Hence the active- or subjectivegenitive, and the passive - or objective-genitive. Here, then, we have an action at the beginning of which stands an active principle or agent and at the end a passive principle or recipient. In between, we have an action in which the recipient is progressively differentiated from the agent in a process of objectification allowing the recipient to be just that, a recipient at the hands of an "other," namely, the "subject." In regard to our question above, the genitive is subjective if "amor Dei" denotes the love God "feels" (Gildersleeve's terminology), or objective if it denotes the love God receives. On this basis my thesis is that des Freux's "amor tui" is an objective genitive. "Tui," as a second person singular mode of address, represents "Dei." "Amor tui," in other words, is the same as "amor Dei" in the sense of an objective genitive. The prayer, then, is about our love for God, rather than God's love for us. Happily, "amor Dei" is the principal example given by Gildersleeve in his treatment of the topic here. I claim that des Freux's expression "amor tui" is immediately recognizable as an objective genitive, for "tui" is the genitive of a relative pronoun representing a person, namely, God, passive recipient of our love. The alternative would be "amor tuus," "your love," that is, God's love for us, in which God and his love are so intimately related as to suggest that the love is that which God feels. This suggestion, however, could be overturned by the context, as we will see. At this point it will be helpful to quote from a message from Kathleen Riley to the author (her qualifications are supplied). She writes, "Certainly I would read amorem tui (even out of context) as an objective or passive genitive (that is, love for you) [...] If it were "your" (that is, God's) love being asked for, it would be amorem tuum."11 Riley continues, "The very fact that we have the genitive of the personal pronoun indicates that it is an objective genitive-and, as you say, quite distinct from the possessive pronoun [I would have said possessive adjective] in gratia tua."

A constructive approach to the same question can be had from Latinist J. B. Allen, ${ }^{12}$ but to access his approach an adjustment has to be made. Allen

$10 \quad$ See Gildersleeve's Latin Grammar (New York: University Publishing Company, 1905), 165 (para no. 363). (My copy is a facsimile.) The book was co-authored by G. Lodge, and is commonly known as "Gildersleeve and Lodge." The best way of referring to it is by paragraph numbers, since these remain constant through varying editions.

11 Letter of Kathleen Riley to author, November 20, 2015. Her qualifications are as follows: BA Hons (Syd) in Latin, MSt and DPhil (Oxon) in Greek and Latin languages and literature.

12 J. B. Allen, An Elementary Latin Grammar (Oxford: OUP, 1930; 1935 reprint), 163, para no. 264. (The first edition was in 1874.) 
discusses "care" (cura) rather than "love." The precise question considered by Allen is how to say in Latin with unmistakable clarity "my care of you" in the sense of "my care for you." It will be clear that the same principle should apply in both cases, that is, to care and to love. Accordingly, des Freux, in saying "amor tui" in V, has affirmed and applied the same law of Latinity in regard to love as is articulated by Allen in regard to care when he writes "mea cura tui." We note further that rather than discuss the question in terms of "subjective genitive" and "objective genitive" as he might have done, Allen has preferred the language of "speaking subjectively" and "speaking objectively." But it needs to be remembered that subjective speech produces an objective genitive: "Mea cura tui" is subjective speech, but "cura tui" is an objective genitive. With "mea cura tui" Allen's speaker is talking about the care he feels for the addressee, who thus becomes "object." The "objective" character of this person is revealed by the use of the word "tui" in their regard.

As Riley and I point out (independently), "cura tui" is not the same as "cura tua" (your care). "Tui" is a pronoun, a substantive, not a possessive adjective like "tua." It stands for a person, the addressee. I will now proceed to argue that the use of the genitive "tui" in regard to love constitutes the principal contribution of des Freux to the correct interpretation of the Suscipe prayer, at least in the mind of des Freux himself. Whether it is also the correct interpretation in the mind of Ignatius remains to be seen. Hence my twofold argument, linguistic and practical. This is important, for on it depends the point (the text and meaning) of my article, which is to convince the reader that of the four sources in the Monumenta, $\mathrm{V}$ provides the best text of the prayer.

A twenty-first-century reader would have no doubt as to the meaning of the last sentence of the prayer in the Prucha card version; it is not at all ambiguous. The love there besought is God's love for me, and the grace is his grace directed to me in a general way to bring me happily to my final end. This is all I ask of him, the only riches I desire. The same can be said of the Puhl and Mullan versions. What place, then, does this prayer have in a "contemplation to attain love" (my emphasis)?

If the meaning given above is true, it would have to be conceded that the prayer is out of place, but St. Ignatius never made that concession. Michael Ivens in his text and commentary has expressed the contrary view that "your love" in A is meant to indicate "my" love for God rather than his love for "me."13 In this respect Ivens, as we will see, is representative of the best in contemporary Jesuit scholarship in English (e.g. Pierre Wolff [b.1929] and George E. Ganss

13 See Michael Ivens, S.J., Understanding the Spiritual Exercises: Text and Commentary; A Handbook for Retreat Directors (Leominster: Gracewing, 1998), 175. 
[1905-2000], to name just two others).${ }^{14}$ If Ivens is correct (as I believe he is), then the prayer is perfectly situated: it asks of God the very love to the acquisition of which the contemplation is dedicated by title. Ivens's justification for this switch is a similar construction he noticed in Exercises no. 15, in which God is said to "inflame" the soul "in his love and praise," where clearly, God is the object, not the subject, of the love mentioned..$^{15}$ On its own Ivens's reason seems slight. This is because he has failed to pay des Freux his due, never acknowledging the essential part he played four centuries earlier in determining the true meaning of the prayer. Unaccountably, there is no mention of des Freux anywhere in Ivens's book, so far as I can discover.

We have now seen that there exist two diametrically opposed ways of interpreting the prayer. Each structures it in its own way. (Let us recall that the earlier sentences are not controverted.) We now look briefly at the two structures, the first being that represented by Mullan and Puhl. The earlier sentences are a heartfelt expression of self-gift to God. This in itself is an expression of love of (for) God. But this theme is then laid aside, to be replaced by a plea for two things, the love of God (for "me") and the gift of his grace (to "me"). At this critical point the prayer collapses back on itself, making a double plea for self. The alternative, that of Ivens and others, sees the final sentence as a continuation of the dynamic of the first part, a plea for one thing only, the gift of an actual love for God in my heart, so that the last part becomes the logical climax of the prayer from its beginning. And it is often claimed that the contemplation to attain love is itself the climax of the Exercises as a whole. My view is that as the alternative structure provides the natural conclusion of the prayer, this in itself constitutes an argument in its favor. To this it can be added that the Contemplatio as a whole is presented by St. Ignatius as a response to God's prior love for us. This is evident not only in the two pre-notes with which it begins, namely, that love is more suitably expressed in actions than in words (230) and that it consists in mutual communication (231), but in the manner of its unfolding. If the Contemplatio stresses the human response, we must never forget that this is all it is, a response. Thus, when the prayer asks for grace, this is the grace that God in his initiative has already given us, the grace by virtue of which the request is made, the grace enabling us to love God in return. It appears idle, therefore, to question the purpose of the request for grace as though

14 See Pierre Wolff, The Spiritual Exercises of Saint Ignatius: A New Translation from the Authorized Latin Text (Liguori, MS: Triumph, 1997), 6o, and George E. Ganss, S.J., The Spiritual Exercises of Saint Ignatius: A Translation and Commentary (Chicago, IL: Loyola Press, 1992), 95 .

15 See Ivens, $175^{\mathrm{n} 23}$. 
it were somehow unclear. God's self-gift to us invites and elicits our self-gift to him supported by his grace.

The des Freux-Ivens interpretation can be bolstered by an appeal, as I will now make, to an example from the liturgy similar to that of the Exercises no. 15 above. As already mentioned, the expression "love of God" is ambiguous. The example I have chosen bears the unusual feature of containing two instances of this kind of ambiguity in the single sentence of the prayer (at Morning Prayer, of Tuesday, Week 4 of the 4-week cycle), which is my reason for choosing it. But the liturgy abounds in such instances, as any person reading the Divine Office in Latin and on the watch for them will soon discover. Here is the prayer: "Auge in nobis, quaesumus, Domine, fidem tuam, ut in ore nostro perfecta laus tua caelestes iugiter afferat fructus."16 The two instances are fidem tuam (your faith) and laus tua (your praise). A strictly literal translation would be: "Increase in us, we pray, Lord, your faith, so that in our mouth your perfect praise may perpetually bear heavenly fruits." A more literary translation would be: "Increase in us, we pray, Lord, our faith in you, so that in our mouths our perfect praise of you may perpetually bear heavenly fruit." Notice that "your faith" has become "our faith" and "your praise" has become "our praise." In each case the context has imposed the switch in perspective. The official translation in my English-language breviary is as follows: "Increase in us, Lord, your gift of faith, so that the praise we offer you may ever yield its fruit from heaven."17 Here the second instance is well handled, but the first, in my opinion, takes an unnecessary (and unjustifiable) liberty with the text.

Despite difference in the time of composition, this example, with others like it, witnesses to a predisposition, a willingness to switch from an objective to a subjective reading should the context suggest or demand it. Thanks to modern-day insistence on clarity and exactitude of expression, this predisposition, while continuing to exist, does so in much reduced form. It was des Freux, at an early stage of Jesuit history, who insisted that the correct understanding of the prayer needed to be anchored in the realm of subjective speech on our part with God as its object. He accomplished this by purely linguistic means of a clarity and exactitude that admitted of no appeal. The possibility of ever returning to an objective reading was thus effectively ruled out. Allow me to illustrate how still today we automatically and instinctively make a switch of perspective when the context requires it. Thus we can say to a friend or colleague who was absent from a meeting, "In your absence we sang your praise," while in other circumstances we can say, paying a compliment, "I greatly value

16 Breviarium Romanum, vol. 4, Per Annum, Week 4 of 4-week cycle, Tuesday, Ad Laudes, 909.

17 The Divine Office, vol. 3, Weeks of the Year, Week 4, Tuesday, Morning Prayer [426]. 
your praise." The same expression, "your praise," with two very different applications and meanings, stemming from different perspectives.

The close relationship between Ignatius the writer and des Freux the translator is well known and does not need documentation from me. It is unthinkable that des Freux would have persisted with his translation, "Amorem tui solum cum gratia tua mihi dones" ("give me only the love of [for] you along with your grace"), in the face of opposition or disagreement from Ignatius. On the contrary, Ignatius must have agreed that this was how he always wanted his prayer understood. He gave a hint to this effect by writing in the A text, "Give me your love and grace, this is enough for me." He did not write "your love and your grace," as Ganss says he did. ${ }^{18}$ In saying "your love and grace," he admitted at least the possibility if not the actuality of detaching the love from the grace, that is, of linking the "your" (in the subjective sense) with the "love" alone, and not with the "grace." Thus Ignatius humanized the love, rendering it the "love of you" in the sense of "my love for you," where the "I" is that of the exercitant, in whose name the Saint speaks, while keeping the grace divine and transcendent, always the grace of God, "your" grace only in the objective sense. The Spanish text adds to our understanding by restricting the relative pronoun "esta" (feminine singular) to "gracia" (also feminine singular), thus admitting the perception that the grace is not a gift separate from the love but precisely the grace of loving God. ${ }^{19}$ It is this grace that is "enough" for me.

Some readers wonder why des Freux used the subjunctive mood for "give" (dones) instead of the imperative (dona or da). I take it that he wished to soften the peremptory tone of the imperative, bearing in mind that he wanted to exhibit a more humble approach to God, especially as he was making a request of him. We English speakers do not seem to notice this or to possess such a high degree of sensitivity, so that we cheerfully make our demands of God, "Give me this" or "grant me that." The use of the subjunctive here is somewhat akin to the instruction of a child to add the polite word "please" to a request.

There is a further word in the Frusian formulation calling for comment, namely, "solum," and to this I now turn. By means of this "solum" ("only") des Freux reinforces the point he has made with the phrase "amorem tui." As an adjective, with its masculine gender and accusative case, it clearly qualifies "amorem tui" and it alone. It makes the point that God is being asked to bestow only one gift (the love) and not two (love and grace). In a second message, of

\footnotetext{
18 Ganss, 184.

19 See Ivens, 175 . Hence his translation of "cum" here as "together with" (174). The same comment applies to Ignatius's use here, for "your," of "vestro" (for a single gift) in distinction from "vestros" (for a double gift).
} 
January 14, 2017, Kathleen Riley remarks, "If two closely joined things (love and grace) were requested, we might reasonably expect the conjunction et or the enclitic -que. That we have neither underscores the instrumental nature of cum. And it would be acceptable to translate cum gratia tua as 'by your grace.' Cum, used in an instrumental sense, occurs sporadically in Silver Latin and more frequently in later periods."

Des Freux being such a determined stylist, it is hard to imagine that he would deliberately use cum instrumentally, but knowing the necessity of grace for the love of (for) God as he undoubtedly did, his recourse to cum cannot be pegged at mere accompaniment, but inevitably surpasses it, amounting in the end to an instrumental usage. In speaking thus, however, I am not attributing the instrumental sense to him; far from it; the indication is that his subjective intention was of the order of accompaniment rather than instrumentality. Had he intended instrumentality, he could have expressed it by the expedient of dropping the cum - "amorem tui solum gratia tua mihi dones"-leaving a simple ablative in its place. His decision in favor of the ambiguous cum shows a deliberate choice of accompaniment over instrumentality, the ambiguity resulting from the fact that cum can equally denote accompaniment or instrumentality. The confusion he thus created precipitated problems down the line, problems that required the corrective intervention of Gueydan.

Theoretically, "solum" can be read as an adverb rather than an adjective, but the following considerations effectively rule this out as a practical possibility. If it is an adjective, it must qualify the exercitant's petition. It is the one thing he or she asks of God; if he grants it, the exercitant will rest content and ask for nothing more. Here "solum" belongs on the side of the exercitant. If on the other hand it is an adverb, it must modify God's attitude. God is told that he is not asked to do very much for the exercitant, in fact this is "the least he could do," as the saying has it. Here "solum" belongs on the side of God. But clearly, this attribution is foreign to the tenor of the prayer as formulated in V. Consider des Freux's carefully crafted line, "amorem tui solum cum gratia tua mihi dones." This breaks down into the three following connected but independent components: "amorem tui solum," "cum gratia tua," and "mihi dones." In the first of these "solum" emerges as unquestionably an adjective. Besides, the "sola" of P1 and $\mathrm{P}_{2}$, on which the "solum" of $\mathrm{V}$ is based, is an adjective.

In asking for grace in the same breath as that in which he asks for love "alone," des Freux, if he is not to be convicted of self-contradiction, acknowledges that love for God cannot be had without grace. In other words, in asking for love he asks, indirectly, also for grace. But the exact relation between the love and the grace eluded him, thus creating a problem requiring Gueydan's solution. There was one "solution" that was not open to des Freux, and that was to 
interpret "grace" as "favor," that is, the personal favor of God toward the exercitant, as we might say today. Here we are speaking not of today, nor of the New Testament era, but of the sixteenth century, with the church on the verge of arguably the most damaging internal dispute in its history, that of grace and free will. This controversy required recognition that to love God as he deserves, grace in the sense of divine help (auxilium divinum) is required. The slightly later existence of the Roman "congregatio de auxiliis" together with the preceding tradition is witness to this. This being the context here, des Freux as a Scholastic would have understood "grace" more or less in terms of the Scholastic "actual" grace. I now proceed to show this.

With his education and personal experience des Freux could not have been ignorant of the Augustinian tradition, reaching down through the Council of Carthage (418) and the Second Council of Orange (529), of the necessity of grace for the love of (for) God. He must have known of the conclusion to its decrees written by Caesarius of Arles, president of the latter council, "According to the texts of Holy Scripture and the explanations of the Holy Fathers quoted above, we must with God's help preach and believe the following: free will has been so distorted and weakened by the sin of the first parent, that thereafter no one could love God as was required, or believe in God, or perform for the sake of God what is good, unless first reached by the grace of the divine mercy."20 By his "cum gratia tua" des Freux acknowledges that the love of (for) God for which he asks is accompanied by God's grace for which he has not asked (directly). Another source of the same tradition, of which des Freux must have known, was St. Thomas Aquinas (1225-74). ${ }^{21}$ Riley sees with complete clarity that accompaniment ("love for God is accompanied by grace") plus necessity ("grace is necessary in order to love God") issues inevitably in instrumentality (cum means "by means of"), and that this should be admitted frankly, as she does. But she is careful not to attribute this understanding to des Freux. As we discussed above, cum is ambiguous: it can denote either accompaniment or instrumentality. Des Freux intended the former even though he was aware of the tradition; Riley sees that in this context there is no escaping the latter.

It is clear that Ivens shares the same awareness of the tradition as des Freux, as he shows in the note of caution that he sounds in the second-to-last sentence of the following quotation, to the effect that human beings cannot rise

20 Jacques Dupuis, The Christian Faith: In the Doctrinal Documents of the Catholic Church (New York: Alba House, 1996), 744.

$21 S$. Th I-II, q. 109, a. 3. Here, Thomas asserts that grace is necessary by reason of the fallen state of humankind. 
to a love worthy of God without the help of grace. My use of the word "rise" is deliberate. Here is the quotation:

The word attain [in the title of the "contemplation to attain love"] is used in the sense not of "obtain" but rather of "reaching to" or "arriving at". The love to be "attained" is a growing love on our part for God. The word attain carries overtones of endeavour, and indeed the whole exercise, consisting as it does in a kind of "pedagogy of love", proposes ways of furthering the development of love on our side. Ultimately, however, the love here sought is a gift and incommensurate with our own endeavours. In the Vulgate the title reads: "Contemplation for arousing spiritual love in ourselves". 22

Ivens's translation simply has "together with." ${ }^{23}$ This is the precise point at which the text, thanks to des Freux, becomes ambiguous. The prayer will stand completely clarified only when this ambiguity is removed; and, as I intend to explain, the person who eventually did this, and did it brilliantly, was Gueydan.

There is nothing corresponding to solum in A's statement. Ignatius had written simply, "Give me your love and grace, this is enough for me." As I have pointed out, "only" makes its appearance in the feminine form "sola" in the $\mathrm{P}$ versions. Restricting our attention to $\mathrm{P} 1$, we observe that this formulation not only supports the same possible detachment of the love from the grace that we noted in A; it positively encourages it by positioning the "tuum" immediately before (instead of after) "amorem," thus leaving the statement of sufficiency to the grace. Des Freux picked up the "sola" from P, but made his own use of it, as we have seen. The reader will note that I am embracing the principle that we should endorse only material compatible with A, that is, with what Ignatius himself wrote.

There is an important kernel of truth in the statement of Ivens that "Your grace' seems best understood not as an addition to the love of God, but precisely as the grace to love God," ${ }^{24}$ namely, its immediate reference to the love of (for) God. Ivens goes on to quote approvingly the translation "Give me the grace to love you." But this, in my view, places (misplaces) the accent on the grace rather than the love. A and V, that is, Ignatius and des Freux, ask for the gift of actual love of God, not just the grace to love him, for actual grace is not always acted on. The alternative "Give me the grace of loving you"

\footnotetext{
22 Ivens, 172.

23 Ivens, 174.

24 Ivens, 175. The next reference to Ivens in this paragraph is also from this page.
} 
escapes this criticism and is acceptable, but it too lacks the directness and simplicity of the Ignatian formulation. There is a sense, then, in which the grace is an addition to the love, namely, in so far as it necessarily accompanies the gift of actual love. Whatever translation we give the phrase, it must be one in which the correct emphasis emerges. Even if this emphasis is "only" a nuance, a nuance itself can be, and in this case is, important. We recognize that the love for God that we feel in our heart is itself a grace. And there is a further difficulty, namely, the danger of becoming mired in technicality, the enemy of devotion. We need to remember that the relevant genre is prayer, not a theology or philosophy lesson. In my view the most successful translation is that of Gueydan, ${ }^{25}$ to whom Ivens refers. His translation runs as follows: "Donnez-moi de vous aimer; donnez-moi cette grâce, voilà qui me suffit," literally, "Give me to love you; give me this grace, which truly is enough for me."

I have three brief observations. First, Gueydan recognizes the principle that to love God appropriately divine grace is necessary. Secondly, he has had recourse to the verbal form of "love," "to love you," rather than the noun form favored by A and V. And thirdly, he has added voilà, which here is suitably translated "truly." Thus, the whole would read, "Grant me only to love you, give me this grace. This, truly, is enough for me."

The essence of Gueydan's solution is the contribution of the word "this," which dissolves the ambiguity introduced by des Freux, circumvents any temptation toward technicality, maintains unscathed the genre of prayer, and upholds the correct emphasis on actual love over grace. True, to reflect the simplicity and directness of A it contains an unavoidable repetition of the petition. But A itself is not perfect either: "your love" is, as we have seen, not free of ambiguity. By his deft stroke, and for these reasons, Gueydan has, in my view, placed himself in the company of des Freux as the other principal contributor to the interpretation of the Suscipe prayer. He has improved on des Freux's "best text," but that is no fault. Let me observe that unless fundamental theology be allowed its legitimate voice, the contribution of des Freux and Gueydan would remain in its present obscurity, and devotees of Jesuit spirituality would continue to be denied the full riches of St. Ignatius's prayer, namely, its authentic text and meaning. We note that both principals were French: let Francophiles rejoice!

What remains to be clarified is the relationship between Exercises nos. 233 and 234. Generally speaking, those who write commentaries on the Exercises are retreat-directors giving advice to other retreat-directors, as can be seen

25 Ignace de Loyola, Exercices spirituels, translation of autograph text by Édouard Gueydan et al. (Paris: Declée de Brouwer, 1986), 140. 
from the subtitles of their books. When, for example, Ivens and Ganss draw attention to the word "grace" at the end of no. 234, it is to make the observation that the "love" there associated with it is the same as that intended by 233 , namely, human love for God. ${ }^{26}$ This is a true and spiritually helpful observation, and one that we can well understand and accept.

However, let us consider no. 233, and learn what St. Ignatius aims to do by this paragraph. (I will use the Ivens translation.) ${ }^{27}$ Ignatius begins by saying that "my" object is "to ask for what I want." He continues, "Here, it will be to ask for interior knowledge of all the good I have received, so that acknowledging this with gratitude, I may be able to love and serve his Divine Majesty in everything." This is an application, in spirituality, of the Scholastic philosophical principle, nihil volitum nisi praecognitum (literally, nothing is willed unless it is previously known). In this case, what is known is, in the first instance, all the good things God has given me in my life. These good things recalled to memory give me a more lively knowledge of God himself, their giver. What is willed is my love, a heightened love, of (for) God, the giver of these goods. Taken as read here is that love is an exercise of the will. The surest way, then, of inflaming my love for God is to recall and savor the good things on which it is based. Note that there is no direct mention of grace here. There is, admittedly, an indirect reference as a comparison with Exercises no. 91 shows. But it remains clear that the emphasis of 233 is the philosophical principle referred to above. Ignatius addresses himself explicitly to the question of grace in the following paragraph, 234. "Patience!" I hear him say, "Not all at once, but all in due order." My point in highlighting this is that "grace" is not an obvious way of referring to the contents of 233 . There is no ground for considering the "grace" of 234 as intended to refer to the contents of 233 , but there is every ground for considering it as intended to refer to 234 itself, to something closer to home, namely, the love that has just been requested.

We come now to the "practical" component of the prayer in its total historical context, that is, the subsequent actions of the Saint in relation to the $\mathrm{V}$ text. There were two such actions. The first was to leave the text and its placing as they were, that is, expressive of human love for God rather than God's love for humans. Thus the text fulfilled eminently the objective of the "contemplation to attain love" in which it occurred, and indeed occurred as its climax. The second action was Saint Ignatius's decision to allow the printing of the $\mathrm{V}$ text only. If this decision did not fulfill all the claims made for it, ${ }^{28}$ it certainly

\footnotetext{
26 Thus Ivens, 175 and Ganss, 184.

27 Ivens, 172.

28 See Jensen, 83 .
} 
demonstrated that V was the Saint's favored text. P2, which was also officially approved, can hardly be said to have encouraged the translation we have in the Prucha card version either, for in saying "tuum amorem et gratiam," it at least allowed, as I have pointed out, the unlinking of the love and the grace, a conception in which love appears as a graced human reality and grace on its own as a purely divine one. Thus I conclude my case that, of the four texts in the Monumenta, V offers the best text of the Suscipe prayer. Des Freux secured that distinction for it by his contribution of the word "tui" to the correct interpretation of the prayer, correct, that is, as the one most in accord with the mind of St. Ignatius as demonstrated in word and deed.

A problem remains, however, as I have intimated, in the fact that readers remain baffled by a literal translation of the final sentence of the prayer in the V version. Take, for example, Ivens's translation: "Give me only the love of you, together with your grace for that is enough for me."29 The reader wants to know what the purpose, the destination, of this grace is, and cannot find an answer in the text. Des Freux evidently considered his formulation to be sufficiently specific; he did not foresee that others might wish to apply it otherwise than to the matter immediately at hand, namely, the grace of loving God, in 234 itself. As things turned out, des Freux's formulation proved insufficient. This is where Gueydan entered the scene with his addition of "this," thus supplying the missing specificity, and updating the best text. The grace is given for the love just mentioned in no. 234: "Give me the love of yourself, give me this grace."

From this the relative importance of the two theologians, des Freux and Gueydan, can be seen. No one can match the importance of des Freux. In standing the last sentence of no. 234 on its head by interpreting it subjectively rather than objectively ([meus] amor tui, [my] love for you), des Freux, as a contemporary and associate of St. Ignatius, initiated, with the latter's endorsement, the modern way of interpreting the Suscipe prayer, which made possible the further and final development achieved by Gueydan in 1986 with his cette ("this"). It is important that these two theologians be given their due, and that is precisely what the present article hopes to do. It also looks for actual change, which hitherto has eluded all criticism, including that of Ivens. Future Jesuit memorial cards should reflect the best in current Jesuit scholarship.

Allow me to conclude by introducing the figure of Edward Caswall, a nineteenth-century English clergyman, scholar, hymn-writer, poet, and translator, of whom many American readers will not have heard, but who made a significant contribution to our question, a contribution that could finish up

29 Ivens, 174. 
being of practical importance for them. Almost all of what I have to say here comes from two relevant web sites. ${ }^{30}$

Caswall was born in 1814 at Yateley, Hampshire, where his father was an Anglican (Episcopal) clergyman. Edward is often referred to as Father Caswall, the title deriving from his ordination as an Anglican priest. Following the death of his wife, he in 1847 under the direct influence of John Henry Newman (1801-90) converted to Catholicism, and in 1850 was admitted to the Congregation of the Oratory at Birmingham, where he remained until his death in 1878 . Upon his admission to the Oratory he sought and obtained Catholic priestly ordination, which enabled him to assist Newman in his parochial and sacramental ministry. ${ }^{31}$ Taking the Latin hymn, $O$ Deus ego amo te, of about 1695 , a paraphrase of the Suscipe prayer of St. Ignatius, he translated it into elegant English verse, and published it under the title, "I Love Thee, O Thou Lord Most High," in five quatrains, in his 1858 collection of poetry, The Masque of Mary. There was no shortage of suitable tunes to which the hymn could be sung. The hymn is of particular interest to us, because it is obviously Frusian in inspiration. A friend of mine learned, and learned to love, the hymn and its Frusian theology at her convent school in Melbourne some sixty years ago. This is what makes me think that some American parishes, especially Jesuit ones, may wish to revive the hymn. The second web site gives the text and music of the hymn under the heading "Prayer of St. Ignatius" from an English hymnal of 1884.

Below I give my suggested translation of the prayer. There is nothing original in it save perhaps the composition of elements from various sources, all of which, hopefully, the reader will recognize. My debt to Gueydan will be obvious.

\section{Suscipe or Oblatio sui}

Take, Lord, all my freedom. Receive my whole memory, understanding, and will. Whatever I have or own, you have given me. I hand it all back to you, and surrender it entirely, to be governed by your will. Grant me only to love you, give me this grace. This, truly, is enough for me.

\footnotetext{
30 https://tosingistopraytwice.wordpress.com/2013/og/o1/i-love-thee-o-thou-lord-most -high/; http://www.hymnary.org/text/i_love_thee_o_thou_lord_most_high (accessed June 7 , 2018). Care needs to be exercised with these sites, as they contain typographical errors. 31 Information obtained from the archivist of the Birmingham Oratory by email, January 13, 2017 .
} 


\section{Appendix}

The four authoritative versions of the Suscipe Prayer: Monumenta Ignatiana, vol. 100. Sancti Ignatii de Loyola Exercitia Spiritualia, 308-9.

\section{Autographum (=A)}

Tomad, Señor, y recibid todo mi libertad, mi memoria, mi entendimiento, y toda mi voluntad, todo mi haber y mi poseer; Vos me lo distes, a Vos Señor, lo torno; todo es vuestro, disponed a toda vuestra voluntad; dadme vuestro amor y gracia que ésta me basta.

Take, Lord, and receive all my liberty, my memory, my understanding, and my entire will. All I own and all I have, You gave to me, to you, Lord, I return it. Everything is yours, dispose of it according to your will. Give me your love and grace, this is enough for me.

Translation (literal): Íñigo Martínez Echevarría

\section{Versio Prima A. $1541(=P 1)$}

Sume et recipe, Domine, totam meam

libertatem, totam memoriam, totum intellectum, totam voluntatem meam; quicquid ego habeo et possideo, de manu tua recepi, et tibi eadem reddo; dispone de illis iuxta beneplacitum voluntatis tuae; infunde mihi tuum amorem et gratiam, quae mihi sola sufficit.

Take and receive, Lord, all my liberty, all my memory, all my understanding, and my entire will; whatever I have or hold, I have received from your hand.

I return it all to you; do with it what you will. Pour into me your love and grace. That alone is enough for me.

Translation: Paul Crittenden

\section{Versio Vulgata $(=V)$}

Suscipe, Domine, omnem meam libertatem. Accipe memoriam, intellectum atque voluntatem omnem. Quicquid habeo vel possideo, mihi largitus es: id 
totum restituo, ac tuae prorsus voluntati trado gubernandum. Amorem tui solum cum gratia tua mihi dones, et dives sum satis, nec aliud quicquam ultra posco.

Take, Lord, all my freedom. Receive my whole memory, understanding, and will. Whatever I have or own, you have given me. I hand it all back to you, and surrender it entirely, to be governed by your will. Grant me only to love you, give me this grace. This, truly, is enough for me.

Translation: Michael Ivens and David Coffey

\section{Versio Prima A. $1547(=P 2)$}

Sume et recipe, Domine, totam meam

libertatem, totam memoriam, totum intellectum, totam voluntatem meam; quicquid ego habeo et possideo, de manu tua recepi, et tibi eadem reddo; dispone de illis iuxta beneplacitum voluntatis tuae; infunde mihi tuum amorem et gratiam, quae mihi sola sufficit.

Take and receive, Lord, all my liberty, all my memory, all my understanding, and my entire will; whatever I have or hold, I have received from your hand.

I return it all to you; do with it what you will. Pour into me your love and grace. That alone is enough for me.

Translation as for $P$ 